\title{
Growth Parameters in Children with Congenital Acyanotic Heart Disease before and after Cardiac Catheterization at Sohag University Hospital
}

\author{
Sylvia Magdy Tamer, Ahmed Monir Hegab, Mohamed Abd El Aal Mohamed \\ Zahraa Elsayed Ahmed \\ Department, Faculty of Medicine, Sohag University, Sohag, Egypt.
}

\begin{abstract}
Background and objectives: Growth failure is common among children with congenital heart disease (CHD). This study aimed at the assessment of the effect of therapeutic cardiac catheterization on the growth status of children with CHD.

Patients and Method: This was a prospective observational study conducted at pediatric cardiac catheterization unit-Sohag university hospital, from October-2016 to September-2017, on children with congenital acyanotic heart diseases who were admitted for therapeutic cardiac catheterization. We assessed the growth parameters as a weight for age Z-score (WAZ), height for age Z-score (HAZ), body mass index and upper arm circumference before catheterization, at one month, three months and six months after catheterization. The growth status was considered normal when WAZ and $\mathrm{HAZ}$ were from $<+2 \mathrm{SD}$ to $>-2 \mathrm{SD}$, underweight if $\mathrm{WAZ}$ was $\leq-2 \mathrm{SD}$ and stunting if HAZ was $\leq-2 \mathrm{SD}$.

Results: One-hundred and two children with congenital acyanotic heart diseases were included. The mean age was $3.95 \pm 3.11$ years. Sixty participants $(58.8 \%)$ were females. Before catheterization,70 patients $(68.6 \%)$ had normal growth status, 20 patients $(19.6 \%)$ had underweight and 19 patients $(18.6 \%)$ had stunting. The prevalence of underweight significantly diminished to3.92\% $(\mathrm{p}<0.001)$ at the $6^{\text {th }}$ month after catheterization. However, no significant differences in the prevalence of stunting were found during the follow-up period.

Conclusion: Therapeutic cardiac catheterization had a significantly positive impact on weight gain shortly after catheterization. However, improvement in the height could not be detected in the first 6 months after catheterization and longer follow-up periods are required.
\end{abstract}

Keywords: Congenital heart disease, Cardiac catheterization, Growth, Children.

\section{Introduction}

Growth failure is common among infants and children with congenital heart disease (CHD) (1). Several studies reported an increased prevalence of growth failure in children with CHD reaching up to $90 \%$ of those children, especially in developing countries $(2,3,4)$. Both underweight and stunting were evident in children with CHD $(2,3)$.

The cause of growth failure associated with CHD is multifactorial. It could be attributed to inadequate caloric intake, mal-absorption or increased metabolic demands. Patients with CHD, who have congestive heart failure or pulmonary hypertension, appear to have an increased prevalence of growth failure (5).

Nowadays, the technical advancements in cardiac imaging, multiple innovative catheter techniques, as well as the availability of cardiac catheterization centers and specialists, have allowed several 
types of congenital heart diseases to be repaired by cardiac catheterization rather than by cardiac surgeries (6). Therapeutic cardiac catheterization has many advantages compared to cardiac surgeries as they have fewer complications, shorter hospitalizations, reduced need for blood transfusion, and lower cost (712).

Several studies revealed that after corrective cardiac surgeries for CHD, the improvement in growth and the restoration of normal development in children occurred within one year $(5,13,14)$. This improvement was attributed to decreasing energy expenditure, increasing dietary intake and recovery of congestive heart failure after corrective cardiac surgeries (15). Although cardiac catheterization can result in similar improvement in cardiovascular physiology and consequently improvement in somatic growth, most studies assessed the somatic growth after corrective surgery for CHD with a lack of studies assessing the growth improvement after cardiac catheterization for children with CHD.

Therefore, this study aimed to assess growth failure in children with cyanotic congenital heart disease before correction and to prospectively assess the growth parameters of these children in the first 6 months after therapeutic cardiac catheterization.

\section{Patients and Methods}

This was a prospective observational study. Children aged 1 month to 12 years who had therapeutic cardiac catheterization procedures for congenital cyanotic heart diseases at the pediatric cardiac catheterization unit, Sohag university hospital throughout 1 year period from October 2016 to September 2017 were included in the study. Therapeutic cardiac catheterization procedures that were done for the participants included atrial septal defect device closure, balloon valvoplasty, patent ductus arteriosus device closure, and ventricular septal defect device closure. Children with associated genetic syndromes, endocrinal, renal, gastrointestinal or neurological diseases that may affect growth were excluded.

The patients were reviewed at the pediatric cardiology clinic before catheterization, at one month, three months and six months after catheterization. The demographic data were collected with thorough direct interviews with children and their parents. The growth parameters as weight, height, body mass index and upper arm circumference were assessed at each clinical visit by the same investigator (the principal researcher) using the same assessment tools. The length was measured for children $<2$ years in a firm box with an inflexible board and fixed headboard, whereas height was measured for those $>2$ years while standing erect against a wall-mounted stadiometer. Weight measurement was done using a properly calibrated pediatric scale. The mid-upper-arm circumference was measured by wrapping a tape around the left upper arm at the mid-point between the tip of the shoulder and elbow. Body mass index (BMI) measurement was done using $\mathrm{BMI}$ formula (BMI= weight ( in kilograms) / $\{$ height ( in meters) $\left.\}^{2}\right)$.

The Z-scores for height for age (HAZ) and weight for age (WAZ) were determined for the study participants using the World Health Organization (WHO) growth curves 
(16). The growth status was considered normal when WAZ and HAZ were from $<+2$ standard deviation $(\mathrm{SD})$ to $>-2 \mathrm{SD}$. The participants were considered to be underweight if WAZ was -2 SD or less while they were considered to have stunting if $\mathrm{HAZ}$ was $-2 \mathrm{SD}$ or less.

Written consents were obtained from the guardians of the study participants. The study protocol was approved by the research ethics committee at the Sohag faculty of medicine.

The statistical analysis was done using SPSS version 18. Continuous variables were expressed as mean and standard deviation, whereas categorical variables were expressed as numbers and ratios. A paired samplet-test or Wilcoxon paired signed-rank test was used to compare paired continuous variables, whereas McNemar's test was used to compare paired categorical variables. P-value was considered significant if it was less than 0.05 .

\begin{tabular}{|l|l|}
\hline Variable & $\begin{array}{l}\text { Summary } \\
\text { statistics }\end{array}$ \\
\hline $\begin{array}{l}\text { Age/year } \\
\text { Mean } \pm \text { SD }\end{array}$ & $3.95 \pm 3.11$ \\
\hline Gender & $60(58.82 \%)$ \\
Females, n (\%) & $42(41.18 \%)$ \\
\hline Pales, n (\%) & $2(1.96 \%)$ \\
\hline Type of CHD, n (\%) & \\
Atrial septal defect & $44(43.14 \%)$ \\
Patent ductus arteriosus & $23(22.55 \%)$ \\
Pulmonary stenosis & $25(24.51 \%)$ \\
Ventricular septal defect & $\mathbf{8}(7.84 \%)$ \\
Atrial septal defect \& Pulmonary stenosis & $2(1.96 \%)$ \\
\hline Underweight, n(\%) & $20(19.61 \%$ \\
\hline Normal, n (\%) & $\mathbf{7 0}(68.63 \%)$ \\
\hline Stunting, n (\%) & $19(18.63 \%)$ \\
\hline & \\
\hline & \\
\hline
\end{tabular}

Table 2 shows the anthropometric parameters before catheterization and at $1^{\text {st }}$ month, $3^{\text {rd }}$ month and $6^{\text {th }}$-month

\section{$\underline{\text { Results }}$}

The study included 102 children with cyanotic congenital heart diseases who were admitted for therapeutic cardiac catheterization. Table 1 shows the demographic and clinical characteristics of the study participants on admission to the cardiac catheterization unit. The mean age of the patients was 3.95 \pm 3.11 years with a range from 1 month to 12 years. Sixty participants $(58.8 \%)$ were females. Forty-four patients $(43.14 \%)$ had an atrial septal defect, 25 patients $(24.51 \%)$ had pulmonary stenosis, 23 patients $(22.55 \%)$ had patent ductus arteriosus, 8 patients $(7.84 \%)$ had a ventricular septal defect and 2 patients $(1.96 \%)$ had atrial septal defect and pulmonary stenosis. Before cardiac catheterization, 70 patients (68.6\%) had normal growth status, whereas 20 patients $(19.6 \%)$ were underweight and 19 patients (18.6\%) had stunting.
Table (1) Demographic and clinical characteristics of the study participants on admission to the cardiac catheterization unit 
visits after catheterization (p-value $<\mathbf{0 . 0 0 1}$ ). Moreover, the mean body mass index (BMI) and upper arm circumference (UAC) showed significant improvements at $3^{\text {rd }}$ month (p-value <0.001) and $6^{\text {th }}$ month (p-

\begin{tabular}{|c|c|c|c|c|}
\hline \multirow{2}{*}{$\begin{array}{c}\text { Anthropometric } \\
\text { parameters }\end{array}$} & \multirow{2}{*}{$\begin{array}{c}\text { Before } \\
\text { catheterizatio } \\
\text { n }\end{array}$} & \multicolumn{3}{|c|}{ post-catheterization (follow- up) } \\
\hline & & 1st month & 3rd month & 6th month \\
\hline $\begin{array}{l}\text { WAZ } \\
\text { Mean (SD) } \\
\text { P-value }\end{array}$ & $-1.29(1.05)$ & $\begin{array}{c}-1.40(1.0) \\
<0.001\end{array}$ & $\begin{array}{l}-0.91(0.98) \\
<0.001\end{array}$ & $\begin{array}{l}-0.35 \\
(0.88) \\
<0.001\end{array}$ \\
\hline $\begin{array}{l}\text { HAZ } \\
\text { Mean (SD) } \\
\text { P-value }\end{array}$ & $-0.79(1.37)$ & $\begin{array}{c}-0.94(1.38) \\
<0.001\end{array}$ & $\begin{array}{c}-0.90(1.32) \\
0.01\end{array}$ & $\begin{array}{l}-0.80 \\
(1.26) \\
0.47 \\
\end{array}$ \\
\hline $\begin{array}{l}\text { BMI } \\
\text { Mean (SD) } \\
\text { P-value } \\
\end{array}$ & $15.10(2.09)$ & $\begin{array}{c}15.13(2.13) \\
0.51\end{array}$ & $\begin{array}{c}15.93(2.36) \\
<0.001\end{array}$ & $\begin{array}{c}16.8(2.61) \\
<0.001\end{array}$ \\
\hline $\begin{array}{l}\text { Upper arm - } \\
\text { circumference } \\
\text { Mean (SD) } \\
\text { P-value }\end{array}$ & $15.16(2.23)$ & $\begin{array}{c}15.17(2.21) \\
0.32\end{array}$ & $\begin{array}{l}15.49(2.19) \\
<0.001\end{array}$ & $\begin{array}{l}16.42 \\
(2.20) \\
<0.001\end{array}$ \\
\hline
\end{tabular}

Table(2):

Anthropometric parameters before and after cardiac catheterization

* WAZ: Weight for age Z-score, HAZ: Height for age Z-score, BMI: Body mass index, SD: standard deviation.
Table 3 demonstrates the growth status before catheterization and at $1^{\text {st }}, 3^{\text {rd }}$ and $6^{\text {th }}$-month follow-up visits. The number of children with underweight significantly decreased 6 months after catheterization (p-value $<\mathbf{0 . 0 0 1 )}$. However, there was no significant difference in the prevalence of stunting at all follow-up visits.

\begin{tabular}{|c|c|c|c|c|}
\hline \multirow{2}{*}{ Growth status } & \multirow{2}{*}{$\begin{array}{c}\text { Before } \\
\text { catheterization }\end{array}$} & \multicolumn{3}{|c|}{ post-catheterization (follow- up) } \\
\hline & & 1st month & 3rd month & 6th month \\
\hline $\begin{array}{l}\text { Underweight, } \\
\text { n(\%) } \\
\text { P-value }\end{array}$ & $20(19.61 \%)$ & $\begin{array}{l}19 \\
\begin{array}{l}(18.63 \%) \\
0.85\end{array}\end{array}$ & $\begin{array}{l}16(15.69 \%) \\
0.46\end{array}$ & $\begin{array}{l}4(3.92 \%) \\
0.001\end{array}$ \\
\hline $\begin{array}{l}\text { Normal, } n \\
(\%) \\
\text { P-value }\end{array}$ & $70(68.63 \%)$ & $\begin{array}{l}\text { 73 } \\
(71.57 \%) \\
\quad 0.64\end{array}$ & $\begin{array}{l}75(73.53 \%) \\
0.44\end{array}$ & $\begin{array}{l}84(82.35 \%) \\
0.02\end{array}$ \\
\hline $\begin{array}{l}\text { Stunting, } n \\
(\%) \\
\text { P-value }\end{array}$ & $19(18.63 \%)$ & $\begin{array}{l}19 \\
\begin{array}{l}(18.63 \%) \\
\quad 1.0\end{array} \\
\end{array}$ & $\begin{array}{c}17(16.67 \%) \\
0.71\end{array}$ & $\begin{array}{l}15(14.71 \%) \\
0.45\end{array}$ \\
\hline
\end{tabular}

Table (3): Growth status before and after cardiac catheterization

\section{Discussion}

Growth failure is prevalent among infants and children with congenital heart disease (CHD) (1). The current study which was conducted on children with cyanotic congenital heart disease found that growth failure was evident in only $38.2 \%$ of those children. This was in line with the finding of Ratanachu and Pongdara (2) who demonstrated that growth failure was evident in $40 \%$ of children with CHD. However, a previous Egyptian study conducted by
Hassan et al. (3) reported that $84 \%$ of children with CHD had growth failure. Similarly, Okoromah et al. (4) detected growth failure in $90.4 \%$ of children with CHD.

Moreover, our study found that $19.61 \%$ of children with congenital acyanotic heart disease had underweight while $18.63 \%$ of them suffered from stunting. Although these finding were similar to 
those reported by Costello et al (1) who found that

$23 \%$ of children with CHD had underweight and $21 \%$ had stunting, our findings were lower than those reported by several other studies as Villasis-

Keever et al (17) (41\% with underweight Vs. 25\% with stunting),

Vaidyanathan et al (18), (59\% with underweight Vs. 26\% with stunting),

Dalili et al (19) $(40.3 \%$ with underweight Vs. $22.6 \%$ with stunting) and Mitchell et al (20) (52\% with underweight Vs. 37\% with stunting).

The lower prevalence of growth failure -either in the form of underweight or stunting- found by this study compared to other studies might be attributed to the inclusion of only children with congenital acyanotic heart diseases in the current study. Hemodynamic changes and consequently growth are more affected in children with congenital cyanotic heart diseases.

The current study found significant improvements in the mean weight for age z-score (WAZ) at all follow-up visits after catheterization. Furthermore, we found that the prevalence of underweight significantly decreased 6 months after catheterization. Similar results were reported by Ratanachu and Pongdara(2), Vaidyanathan et al (18) and Vaidyanathan et al (21). On the other hand, there was no improvement in the height for age z-score (HAZ) within the first 6 months after catheterization. Similar findings were reported by Vaidyanathan et al (18), Oyarzún et al (22) and Tamayo et al (23).

The study had some limitations. First, it was a single-center study so that the results may not be generalizable to a broader population. Second, the 6 month follow-up period was not sufficient to detect changes in the height of the study participants and longer follow-up periods are required.

\section{Conclusion}

Growth failure -either in the form of underweight or stunting- was common among children with acyanotic congenital heart disease. Therapeutic cardiac catheterization had a significantly positive impact on weight gain shortly after catheterization. However, improvement in the height could not be detected in the first 6 months after catheterization and longer follow-up periods are required.

Conflicts of interest: There is no conflict of interest to be declared.

\section{References}

1- Costello CL, Gellatly M, Daniel J, Justo RN, Weir K. Growth Restriction in infants and young children with congenital heart disease. Congenit Heart Dis. 2015;10(5):447-456.

2- Ratanachu-EK, Pongdara A. Nutritional status of pediatric patients with congenital heart disease: pre-and post-cardiac surgery. J Med Assoc Thai. 2011;94(3):133-137.

3- Hassan BA, Albanna EA, Morsy SM, Siam AG, Al Shafie MM, Elsaadany HF, Sherbiny HS, Shehab $M$ and Grollmuss O. Nutritional status in children with unoperated congenital heart disease: an Egyptian center experience. Front. Pediatr. 2015;53(3):1-5.

4- Okoromah CAN, Ekure EN, Lesi FE, Okunowo WO, Tijani BO, Okeiyi JC. Prevalence, profile and predictors of malnutrition in children with congenital heart defects: a case-control observational study. Arch Dis Child. 2011; 96(4):354360.

5- Peres MB, Croti UA, Godoy MF, De Marchi CH, Hassem Sobrinho S, Beani L, Moscardini AC, Braile DM. Evolution of weight and height of children with congenital heart disease undergoing surgical treatment. Rev Bras Cir Cardiovasc. 2014;29(2):241-248.

6- Kim SH. Recent advances in pediatric interventional cardiology. Korean J Pediatr. 2017; 60(8):237-244.

7- Sun K. Advances in pediatric interventional catheterization. J Clin Pediatr. 2008;26(5):365-70. 
8- Berger F., Vogel M., Alexi-Meskishvili V., Lange P.E. Comparison of results and complications of surgical and Amplatzer device closure of atrial septal defects. J. Thorac. Cardiovasc. Surg. 1999;118:674678.

9- Du Z.D., Hijazi Z.M., Kleinman C.S. Comparison between transcatheter and surgical closure of secundum atrial septal defect in children and adults: Results of multicenter nonrandomized trial. J. Am. Coll. Cardiol. 2002;39:1836-1844.

10-Kim J.J., Hijazi Z.M. Clinical outcomes and costs of Amplatzer transcatheter closure as compared with surgical closure of ostium secundum atrial septal defects. Med. Sci. Monit. 2002;12: CR787CR791.

11- Animashaun BA, Adekunle MO, False O, Gidado MT, Kusimo OY, Sanusi MO, Johnson A. Is transcatheter closure superior to surgical ligation of patent ductus arteriosus among Nigerian Children?. Afr J Paediatr Surg 2018;15:100-3.

12- Nady ME, Amrousy DE, Salah $N$ and Zoair A. Transcatheter Versus Surgical Closure of Patent Ductus Arteriosus in Pediatric Patients: A Systematic Review With Meta-Analysis. SM J Pediatr Surg. 2017; 3(4): 1054.

13- Tokel K, Azak E, Ayabakan C, Varan B, Aşlamaci SA, Mercan S. Somatic growth after corrective surgery for congenital heart disease. Turk J Pediatr. 2010; 52(1):58-67.

14- Bravo-Valenzuela NJM, Passarelli MLB, Coates MV, Nascimento LFC. Recuperação pôndero-estatural em crianças com síndrome de Down e cardiopatia congênita. Rev Bras Cir Cardiovasc. 2011; 26(1):61-68.

15-Surmeli-Onay O, Cindik N, Kinik ST, Ozkan S, Bayraktar N, Tokel K. The effect of corrective surgery on serum IGF-1 and IGFBP-3 levels and growth in children with congenital heart disease. J Pediatr Endocrinol Metab. 2011; 24(7-8):483-487.

16-WHO. Multicentre Growth Reference Study Group. WHO Child Growth Standards: Length/height-for-age, weightfor-age, weight-for-length, weight-forheight and body mass index for- age: Methods and development. Geneva: World Health Organization; 2006.
17- Villasis-Keever MA, Aquiles Pineda-Cruz R, Halley-Castillo E, Alva-Espinosa C. Frequency and risk factors associated with malnutrition in children with congenital cardiopathy. Salud Publica Mex. 2001; 43(4): 313-323.

18- Vaidyanathan B, Radhakrishnan R, Sarala DA, Sundaram KR, Kumar RK. What determines nutritional recovery in malnourished children after correction of congenital heart defects? Pediatrics. 2009;124(2):294-299.

19- Dalili M, Meraji SM, Davari P, Moghaddam MY, Abkenar HB, Vahidi A, and Shahmohammadi A. Growth Status of Iranian Children with Hemodynamically Important Congenital Heart Disease.Acta Medica Iranica. 2011; 49(2): 103-108.

20- Mitchell IM, Logan RW, Pollock JC, Jamieson MP. Nutritional status of children with congenital heart disease. $\mathrm{Br}$ Heart J. 1995; 73(3): 277-283.

21-Vaidyanathan B, Nair SB, Sundaram KR, Babu UK, Shivaprakasha K, Rao SG, Kumar RK. Malnutrition in children with congenital heart disease (CHD): determinants and short term impact of corrective intervention. Indian Pediatr. 2008;45(7):541-546.

22- Oyarzon I., Claveria C., Larios G., Le Roy C. Nutritional recovery after cardiac surgery in children with congenital heart disease. Rev Chil Pediatr. 2018;89(1):2431 .

23-Tamayo C, Manlhiot C, Patterson K, Lalani S, McCrindle BW. Longitudinal evaluation of the prevalence of overweight/obesity in children with congenital heart disease. Can J Card. 2015;31(2):117-123. 